THE BARDN'S CLDAK 



\title{
THE BARDN'5 CLDAK
}

\author{
A History of the Russian Empire \\ in War and Revolution
}

\section{UILLARD 5UNDERLAND}


Copyright (C) 2014 by Cornell University

All rights reserved. Except for brief quotations in a review, this book, or parts thereof, must not be reproduced in any form without permission in writing from the publisher. For information, address Cornell University Press, Sage House, 512 East State Street, Ithaca, New York 14850.

First published 2014 by Cornell University Press

Printed in the United States of America

\section{Library of Congress Cataloging-in-Publication Data}

Sunderland, Willard, 1965- author.

The baron's cloak : a history of the Russian Empire in war and revolution / Willard Sunderland.

pages $\mathrm{cm}$

Includes bibliographical references and index.

ISBN 978-0-8014-5270-3 (cloth : alk. paper)

1. Ungern-Sternberg, Roman, 1885-1921. 2. Generals-RussiaBiography. 3. Generals-Soviet Union-Biography. 4. Soviet UnionHistory-Revolution, 1917-1921. 5. Siberia (Russia)-HistoryRevolution, 1917-1921. 6. Mongolia-History, Military-20th century. 7. Russia-Description and travel. 8. Soviet Union-Description and travel. I. Title.

DK254.U5S86 2014

947.08'3092-dc23

[B] 2013045239

Cornell University Press strives to use environmentally responsible suppliers and materials to the fullest extent possible in the publishing of its books. Such materials include vegetable-based, low-VOC inks and acid-free papers that are recycled, totally chlorine-free, or partly composed of nonwood fibers. For further information, visit our website at www.cornellpress.cornell.edu.

Cloth printing

10998756545321 
For HM 
In the beginning. all the arrangements for building the Tower of Babel were in fairly good order.

-Franz KaFka, "The City Coat of ARMs" 